\title{
REVIEW
}

\section{Inborn errors of metabolism as a cause of neurological disease in adults: an approach to investigation}

\author{
R G F Gray, M A Preece, S H Green, W Whitehouse, J Winer, A Green
}

West Midlands Regional Metabolic Disease Service, Birmingham Children's Hospital NHS Trust, Steelhouse Lane, Birmingham B4 6NH, UK

R G F Gray

M A Preece

A Green

\section{Department of Neurology, Diana, Princess of Wales Children's Hospital NHS Trust, \\ Birmingham, UK \\ S H Green \\ W Whitehouse}

Department of Neurology, University Hospital NHS Trust, Birmingham, UK

$\mathrm{J}$ Winer

Correspondence to: Dr R G F Gray

George.Gray@bhamchildrens wmids.nhs.uk

Received 12 February 1999 and in revised form 26 November 1999 Accepted 5 January 2000
In 1927 Archibald Garrod presented the Huxley Lecture at Charing Cross Hospital ${ }^{1}$ Out of this lecture emerged the concept of an "inborn error of metabolism" whereby an inherited defect may lead to the accumulation in cells or body fluids of a metabolite which in itself may predispose to disease. The disorders cited as examples were all adult onset disorders.

Today there are over 200 known inborn errors of metabolism; however, the vast majority of cases reported are of childhood onset $(<16$ years of age). In part this may reflect the fact that the paediatric forms of the disease are more severe and hence more easily recognisable. However, in some cases it may be due to a lack of awareness by physicians treating adults of the possibility of inborn errors of metabolism being a cause of disease. Certainly, current experience of inborn errors of metabolism leads us to think that, potentially, every disorder has a milder form with a later onset.

In an attempt to increase awareness of adult onset inborn errors of metabolism this article reviews the disorders which can present at or older than 16 years of age with CNS or neuromuscular disease. We have included disorders in which the patient may present with mild or "soft" signs before that age, which are likely to be overlooked or mistaken for other disorders. This is not intended to be an in depth review of each disorder but rather to be a practical guide to the initial diagnosis of these disorders for neurologists outside specialist centres for the investigation of inborn errors of metabolism.

\section{The disorders}

We have prepared two tables listing inborn errors of metabolism presenting in adulthood.

Table 1 lists the disorders reported in the literature together with the main clinical symptoms, primary defect (if known), and diagnostic tests for their detection.

Table 2 lists the disorders associated with specific symptom groups together with any specific neurological signs and characteristic non-neurological features. Diseases are categorised in a specific group based on the symptom(s) which is the major feature of the disorder, and may in some cases be the initial presenting symptom.
LYSOSOMAL STORAGE DISEASES

The lysosome is an intracellular organelle involved in the degradation of various complex lipids, glycoproteins, and mucopolysaccharides. Defects in specific enzymes lead to the accumulation of complex catabolic intermediates. Although the process occurs in utero the age of onset of clinical symptoms can vary substantially. Alleles are known which are associated with a milder, later onset phenotype. This may be related to the presence of significant residual functional enzyme activity resulting in a lower rate of accumulation of the intermediate metabolite. The clinical symptoms of the adult onset forms of these diseases can differ substantially from the childhood onset forms. This disparity between the text book description of the "classic" phenotype and the reality of the presentation in adults can cause considerable diagnostic difficulty.

Tay-Sach's and Sandhoff's diseases are gangliosidoses which present in the infantile period with seizures, blindness, hypotonia, and developmental delay. The adult onset forms present with a much wider clinical range varying from atypical forms of motor neuron disease $^{2}$ to dystonia ${ }^{3}$ and bulbospinal neuronopathy. ${ }^{4}$

Metachromatic leukodystrophy presents (in its severe form) in the first 2 years of life with spastic paraparesis and developmental delay whereas in the adult form it is associated with dementia and behavioural problem. ${ }^{5}$

Acid maltase deficiency (glycogen storage disease type II) usually presents in the first weeks of life with hypotonia and hypertrophic cardiomyopathy. The adult onset forms may present with muscle weakness but without obvious cardiomyopathy. ${ }^{6}$

Some of the lysosomal enzymes show a "pseudodeficiency" state. Enzyme activity, although reduced to as little as $5 \%$ of normal, does not produce clinical symptoms. In any patient who does not show the typical phenotype but who shows a gross enzyme deficiency this state needs to be excluded by demonstration of the accumulating metabolite or by analysis of the relevant gene. This is particularly a problem with metachromatic leukodystrophy, where $1 / 50-1 / 100$ of the population are 
Table 1 Inherited metabolic disorders with adult onset forms

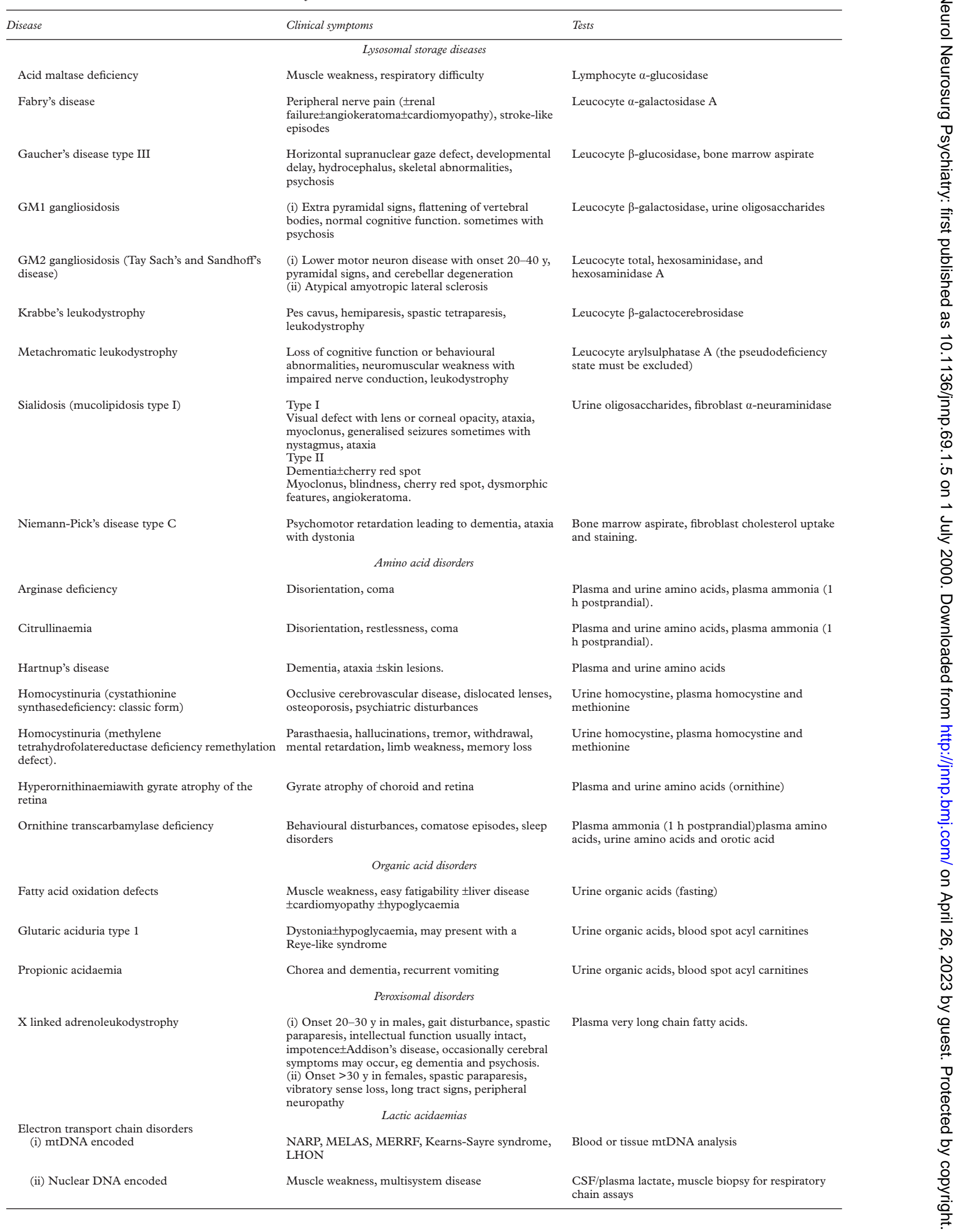


Table 1 Inherited metabolic disorders with adult onset forms (continued)

\begin{tabular}{|c|c|c|}
\hline Disease & Clinical symptoms & Tests \\
\hline \multicolumn{3}{|c|}{ Disorders of the glycogenolytic and glycolytic pathway } \\
\hline Glycogen storage diseases & $\begin{array}{l}\text { Muscle weakness, cardiomyopathy, hepatomegaly, } \\
\text { hypoglycaemia, myopathy }\end{array}$ & $\begin{array}{l}\text { Muscle enzyme assays, but many of the glycogen } \\
\text { storage diseases can be diagnosed by leucocyte or } \\
\text { erythrocyte enzyme assays }\end{array}$ \\
\hline Glycolytic pathway disorders & $\begin{array}{l}\text { Muscle weakness (second wind phenomenon), } \\
\text { exercise intolerance, myoglobinuria } \\
\pm \text { haemolytic anaemia }\end{array}$ & $\begin{array}{l}\text { Muscle enzyme assays, but many of the glycolytic } \\
\text { disorders can be diagnosed by erythrocyte enzyme } \\
\text { assay }\end{array}$ \\
\hline \multicolumn{3}{|c|}{ Other disorders } \\
\hline Abetalipoproteinaemia & Ataxia, retinitis pigmentosa & $\begin{array}{l}\text { Plasma cholesterol, blood film (acanthocytes), } \\
\text { lipoproteins }\end{array}$ \\
\hline Acaeruloplasminaemia & $\begin{array}{l}\text { Ataxia, retinal dystrophy } \pm \text { diabetes mellitus } \pm \text { presenile } \\
\text { dementia }\end{array}$ & Plasma and urine copper, plasma iron and ferritin \\
\hline Adult polyglucosan body disease & $\begin{array}{l}\text { Upper and lower motor neuron signs, sensory loss, } \\
\text { neurogenic bladder, dementia }\end{array}$ & $\begin{array}{l}\text { Leucocyte glycogen brancher enzyme (some forms } \\
\text { may show normal muscle activity). }\end{array}$ \\
\hline Cerebrotendinous xanthomatosis & Spasticity, ataxia, cataracts, tendon xanthomas & Urine bile alcohols \\
\hline Hereditary vitamin E deficiency & $\begin{array}{l}\text { Tremor, ataxia, head titubation, loss of vibration } \\
\text { sense. }\end{array}$ & $\begin{array}{l}\text { Plasma vitamin E, plasma cholesterol and } \\
\text { triglycerides }\end{array}$ \\
\hline $\begin{array}{l}\text { Homocystinuria and methylmalonic aciduria } \\
\text { (combined defect) }\end{array}$ & Megaloblastic anaemia, dystonia & Urine organic acids and homocystine \\
\hline Juvenile Batten's disease & Seizures, visual loss, dementia & $\begin{array}{l}\text { Skin or rectal biopsy for histological analysis, DNA } \\
\text { analysis for the common mutation }\end{array}$ \\
\hline Kuf's disease & $\begin{array}{l}\text { Type A } \\
\text { Progressive myoclonic epilepsy } \\
\text { Type B } \\
\text { Motor problems, psychosis, dementia }\end{array}$ & Skin or rectal biopsy for histological analysis \\
\hline Lesch-Nyhan syndrome & $\begin{array}{l}\text { Some forms may present late with choreiform } \\
\text { movements, dysarthria } \pm \text { renal problems }\end{array}$ & Plasma urate and urine, urate/creatinine \\
\hline Porphyrias & $\begin{array}{l}\text { Limb, neck, and chest pain, muscle weakness, sensory } \\
\text { loss, seizures, behavioural abnormalities } \pm \text { abdominal } \\
\text { symptoms } \pm \text { photosensitivity }\end{array}$ & $\begin{array}{l}\text { Urine delta amino laevulinic acid and } \\
\text { porphobilinogen, urine and fecal porphyrins }\end{array}$ \\
\hline Pyridoxine responsive seizures & Persistent seizures responsive to pyridoxine & $\begin{array}{l}\text { In vivo pyridoxine response test: primary defect not } \\
\text { known }\end{array}$ \\
\hline Refsum's disease & $\begin{array}{l}\text { Retinitis pigmentosa, peripheral polyneuropathy, } \\
\text { cerebellar ataxia }\end{array}$ & Plasma phytanic acid \\
\hline Segawa disease & Cyclical dystonia & $\begin{array}{l}\text { Levodopa trial (some forms have a defect in } \\
\text { biopterin metabolism) }\end{array}$ \\
\hline Sjogren-Larrson syndrome & Spastic tetraplegia \pm ichthyosis, mental retardation & Fibroblast fatty alcohol, oxidoreductase assay \\
\hline Wilson's disease & $\begin{array}{l}\text { Dysarthria, loss of coordination of voluntary } \\
\text { movements, pseudobulbar palsy, parkinsonian } \\
\text { features, renal failure, liver disease, Kayser-Fleischer } \\
\text { rings, dementia }\end{array}$ & $\begin{array}{l}\text { Urine copper (pre and postpenicillamine) } \\
\text { Plasma copper and caeruloplasmin }\end{array}$ \\
\hline
\end{tabular}

Table 2 Symptom groups associated with adult onset inborn errors of metabolism

\begin{tabular}{|c|c|c|}
\hline Disorder & Other symptoms & Tests \\
\hline \multicolumn{3}{|c|}{ Muscle weakness or exercise intolerance } \\
\hline Fatty acid oxidation defects & $\begin{array}{l} \pm \text { Cardiomyopathy } \pm \text { hypoglycaemia } \pm \text { liver } \\
\text { disease } \pm \text { myoglobinuria }\end{array}$ & Urine organic acids (fasting) \\
\hline Glycolytic pathway disorders & $\begin{array}{l} \pm \text { Anaemia } \pm \text { liver disease, muscle weakness } \\
\pm \text { cardiomyopathy } \pm \text { endocrinological disorders } \pm \text { ptosis }\end{array}$ & Red cells or muscle biopsy for enzyme assays \\
\hline $\begin{array}{l}\text { Glycogen storage diseases } \\
\text { (a) Type II (acid maltase deficiency) }\end{array}$ & $\begin{array}{l} \pm \text { Respiratory difficulties due to diaphragmatic } \\
\text { weakness }\end{array}$ & Lymphocyte acid $\alpha$-glucosidase \\
\hline $\begin{array}{l}\text { (b) Type III (Cori's disease) } \\
\text { (c) Type V (McArdle's disease) } \\
\text { (d) Phosphorylase b kinase deficiency }\end{array}$ & $\begin{array}{l}\text { History of early hypoglycaemia and hepatomegaly } \\
\text { Myoglobinuria, exercise intolerance, cramps } \\
\pm \text { Cardiomyopathy } \pm \text { liver disease }\end{array}$ & $\begin{array}{l}\text { Leucocyte glycogen debrancher enzyme assay } \\
\text { Ischaemic exercise test } \\
\text { Erythrocyte or liver phosphorylase b kinase assay }\end{array}$ \\
\hline Myoadenylate deaminase deficiency & Note: most persons are asymptomatic & $\begin{array}{l}\text { Ischaemic exercise test (increased ammonia), muscle } \\
\text { biopsy for myoadenylate deaminase assay, blood for } \\
\text { DNA analysis for the common mutation. }\end{array}$ \\
\hline
\end{tabular}


Table 2 Symptom groups associated with adult onset inborn errors of metabolism (continued)

\begin{tabular}{|c|c|c|}
\hline Disorder & Other symptoms & Tests \\
\hline \multicolumn{3}{|c|}{ Motor neuron disease } \\
\hline Adult polyglucosan storage disease & Dementia, neurogenic bladder, sensory loss & $\begin{array}{l}\text { Leucocyte glycogen brancher assay (some forms may } \\
\text { show normal muscle activity). }\end{array}$ \\
\hline $\begin{array}{l}\text { GM2 Gangliosidosis (Tay-Sach's and Sandhoff's } \\
\text { disease) }\end{array}$ & $\begin{array}{l}\text { Slow progressive disorder, pyramidal signs, cerebellar } \\
\text { degeneration }\end{array}$ & $\begin{array}{l}\text { Leucocyte total hexosaminidase and hexosaminidase } \\
\text { A }\end{array}$ \\
\hline \multicolumn{3}{|c|}{ Chorea and/or dystonia } \\
\hline Glutamic aciduria type 1 & $\begin{array}{l} \pm \text { Reye’s syndrome } \\
\pm \text { Hypoglycaemia, slow progressive disorder, gait } \\
\text { disturbance, dysarthria }\end{array}$ & $\begin{array}{l}\text { Urine organic acids } \\
\text { blood spot for acyl carnitines }\end{array}$ \\
\hline $\begin{array}{l}\text { GM2 Gangliosidosis (Tay-Sach's and Sandhoff's } \\
\text { disease) }\end{array}$ & Slow progressive disorder & $\begin{array}{l}\text { Leucocyte total hexosaminidase and hexosaminidase } \\
\text { A }\end{array}$ \\
\hline Lesch-Nyhan syndrome & Renal stones & Plasma urate and urine, urate/creatinine ratio \\
\hline Methylmalonic aciduria with homocystinuria & \pm Anaemia & $\begin{array}{l}\text { Urine organic acids and amino acids. urine, and } \\
\text { plasma homocystine. }\end{array}$ \\
\hline Niemann-Pick disease type $\mathrm{C}$ & $\begin{array}{l}\text { Supranuclear ophthalmoplegia, ataxia, psychomotor } \\
\text { retardation, dementia, splenomegaly }\end{array}$ & $\begin{array}{l}\text { Bone marrow aspirate fibroblast cholesterol } \\
\text { incorporation and staining }\end{array}$ \\
\hline Segawa disease & Diurnal variation of symptoms & $\begin{array}{l}\text { Levodopa trial (some forms have a defect in } \\
\text { biopterin metabolism) }\end{array}$ \\
\hline Wilson's disease & $\begin{array}{l}\text { Kayser-Fleischer rings }, \pm \text { liver disease } \pm \text { dementia } \\
\pm \text { choreoathetosis } \pm \text { renal failure }\end{array}$ & $\begin{array}{l}\text { Plasma copper and caeruloplasmin, urine copper } \\
\text { (pre and postpenicillamine), liver copper }\end{array}$ \\
\hline \multicolumn{3}{|c|}{ Ataxia } \\
\hline Abetalipoproteinaemia & $\begin{array}{l}\text { Muscle weakness, fat malabsorption, retinitis } \\
\text { pigmentosa }\end{array}$ & $\begin{array}{l}\text { Plasma cholesterol and triglycerides, blood film } \\
\text { (acanthocytes), lipoproteins }\end{array}$ \\
\hline Acaeruloplasminaemia & $\begin{array}{l} \pm \text { Presenile dementia } \pm \text { diabetes mellitus, retinal } \\
\text { dystrophy }\end{array}$ & Plasma and urine copper \\
\hline Cerebrotendinous xanthomatosis & Spasticity, cataracts, tendon xanthomas & Urine cholestanol \\
\hline $\begin{array}{l}\text { GM2 Gangliosidosis (Tay-Sachs' and Sandhoff's } \\
\text { disease) }\end{array}$ & Slow progressive disorder & $\begin{array}{l}\text { Leucocyte total hexosaminidase and hexosaminidase } \\
\text { A }\end{array}$ \\
\hline Hartnup disease & \pm Skin lesions & Plasma and urine amino acids \\
\hline Niemann-Pick disease type C & $\begin{array}{l} \pm \text { Supranuclear ophthalmoplegia, dementia, dystonia, } \\
\text { splenomegaly }\end{array}$ & Bone marrow aspirate \\
\hline Pyruvate dehydrogenase deficiency (X linked) & Episodes in males triggered by carbohydrate feeding & $\begin{array}{l}\text { Pre and postprandial blood lactate, CSF lactate, } \\
\text { fibroblast pyruvate dehydrogenase }\end{array}$ \\
\hline Refsum's disease & Retinitis pigmentosa, polyneuropathy & Plasma phytanic acid \\
\hline Sialidosis (mucolipidosis type I) & $\begin{array}{l}\text { Type I } \\
\text { Visual defect with lens or corneal opacity, ataxia, } \\
\text { myoclonus, generalised seizures sometimes with } \\
\text { nystagmus, ataxia, dementia } \pm \text { cherry red spot } \\
\text { Type II } \\
\text { Myoclonus, blindness, cherry red spot, dysmorphic } \\
\text { features, angiokeratoma. }\end{array}$ & $\begin{array}{l}\text { Urine oligosaccharides } \\
\text { fibroblast } \alpha \text {-neuraminidase }\end{array}$ \\
\hline \multicolumn{3}{|c|}{ Leukodystrophy (diagnosed radiologically) } \\
\hline Krabbe’s leukodystrophy & Pes cavus, hemiparesis, spastic tetraparesis & Leucocyte $\beta$-galactocerebrosidase \\
\hline Metachromatic leukodystrophy & $\begin{array}{l}\text { Slow progressive disorder, impaired nerve } \\
\text { conduction } \pm \text { behavioural problems }\end{array}$ & $\begin{array}{l}\text { Leucocyte arylsulphatase A (common } \\
\text { pseudodeficiency state must be excluded) }\end{array}$ \\
\hline $\mathrm{X}$ linked adrenoleukodystrophy & $\begin{array}{l}\text { Males } \\
\text { Gait disturbance, spastic paraparesis, rarely dementia } \\
\pm \text { Addison’s disease } \\
\text { Females } \\
\text { Onset }>30 \text { y, spastic paraparesis, vibration sense loss, } \\
\text { long tract signs, peripheral neuropathy }\end{array}$ & Plasma very long chain fatty acids \\
\hline \multicolumn{3}{|c|}{ Strokes and stroke-like episodes: } \\
\hline Fabry's disease & Angiokeratoma, renal disease, developmental delay & Leucocyte $\alpha$-galactosidase A \\
\hline Homocystinuria & $\begin{array}{l}\text { Lens dislocation,occlusive cerebrovascular disease, } \\
\text { osteoporosis, skeletal deformities, mental retardation }\end{array}$ & Urine homocystine \\
\hline $\begin{array}{l}\text { Mitochondrial myopathy, encephalopathy with } \\
\text { lactic acidaemia and stroke-like episodes } \\
\text { (MELAS) }\end{array}$ & $\begin{array}{l}\text { Seizures, developmental delay, sensorineural hearing } \\
\text { loss } \pm \text { diabetes mellitus }\end{array}$ & Blood for mtDNA analysis \\
\hline Urea cycle defects & Postprandial vomiting, coma, confusion & Blood ammonia, plasma, and urine amino acids \\
\hline
\end{tabular}


Table 2 Symptom groups associated with adult onset inborn errors of metabolism (continued)

\begin{tabular}{|c|c|c|}
\hline Disorder & Other symptoms & Tests \\
\hline & \multicolumn{2}{|l|}{ Behavioural and/or psychiatric disorders and/or dementia } \\
\hline Acaeruloplasminaemia & Ataxia, diabetes mellitus, retinal dystrophy & $\begin{array}{l}\text { Plasma copper and caeruloplasmin, plasma iron and } \\
\text { ferritin }\end{array}$ \\
\hline Gaucher's disease type III & $\begin{array}{l}\text { Horizontal supranuclear gaze defect, developmental } \\
\text { delay, hydrocephalus, skeletal abnormalities } \\
\text { psychosis }\end{array}$ & Leucocyte $\beta$-glucosidase, bone marrow aspirate \\
\hline Hartnup disease & Ataxia and skin lesions & Plasma and urine amino acids \\
\hline Homocystinuria (classic) & $\begin{array}{l}\text { Occlusive cerebrovascular disease, dislocated lenses, } \\
\text { osteoporosis, skeletal deformities. }\end{array}$ & Urine and plasma homocystine and methionine. \\
\hline Homocystinuria (remethylation defect) & Paraesthesia, limb weakness, mental retardation & Urine and plasma homocystine and methionine. \\
\hline Juvenile Batten's disease & Visual loss, seizures, retinitis pigmentosa & $\begin{array}{l}\text { Skin or rectal biopsy for histological analysis, DNA } \\
\text { for the common deletion }\end{array}$ \\
\hline Kuf's disease & Dementia, psychosis, motor loss & Skin or rectal biopsy for histological analysis \\
\hline Metachromatic leukodystrophy & $\begin{array}{l}\text { Slow progressive disorder, impaired nerve } \\
\text { conduction, leukodystrophy }\end{array}$ & $\begin{array}{l}\text { Leucocyte arylsulphatase A (pseudodeficiency state } \\
\text { must be excluded) }\end{array}$ \\
\hline Niemann-Pick disease type C & $\begin{array}{l}\text { Vertical supranuclear ophthalmoplegia, psychomotor } \\
\text { retardation, ataxia, dystonia, splenomegaly }\end{array}$ & $\begin{array}{l}\text { Bone marrow aspirate, fibroblast cholesterol } \\
\text { incorporation and staining }\end{array}$ \\
\hline Ornithine transcarbamylase deficiency & $\begin{array}{l}\text { Episodic symptoms (often postprandial), sleep } \\
\text { disorders, comatose episodes }\end{array}$ & $\begin{array}{l}\text { Plasma ammonia ( } 1 \mathrm{~h} \text { postprandial), plasma amino } \\
\text { acids, urine amino acids and orotic acid }\end{array}$ \\
\hline Porphyriria & $\begin{array}{l}\text { Limb, neck, or chest pain, muscle weakness, } \\
\text { abdominal pain, photosensitivity. }\end{array}$ & $\begin{array}{l}\text { Urine and fecal porphyrins, urine delta } \\
\text { aminolaevulinic acid and porphobilinogen }\end{array}$ \\
\hline Wilson's disease & $\begin{array}{l}\text { Kayser-Fleischer rings } \pm \text { liver disease, dysarthria, loss } \\
\text { of coordination, pseudobulbar palsy, parkinsonian } \\
\text { features }\end{array}$ & Plasma copper and caeruloplasmin \\
\hline $\mathrm{X}$ linked adrenoleukodystrophy & $\begin{array}{l}\text { Gait disturbance } \pm \text { Addison's disease } \\
\text { leukodystrophy, spastic paraparesis, impotence }\end{array}$ & Plasma very long chain fatty acids \\
\hline \multicolumn{3}{|c|}{ Eye disorders } \\
\hline Cerebrotendinous xanthomatosis & Spasticity, cataracts, tendon xanthomas & Urine cholestanol \\
\hline Galactokinase deficiency & Cataracts & Postprandial urine sugar, chromatography \\
\hline Gaucher's disease type III & $\begin{array}{l}\text { Horizontal supranuclear gaze defect, developmental } \\
\text { delay, hydrocephalus, skeletal abnormalities, } \\
\text { psychosis }\end{array}$ & Leucocyte $\beta$-glucosidase \\
\hline Homocystinuria (classic form) & $\begin{array}{l}\text { Lens dislocation, occlusive cerebrovascular disease, } \\
\text { osteoporosis, skeletal deformities, mental retardation }\end{array}$ & Urine and plasma homocystine and methionine \\
\hline $\begin{array}{l}\text { Hyperornithinaemia with gyrate atrophy of the } \\
\text { retina }\end{array}$ & Optic atrophy & Plasma and urine amino acids (ornithine) \\
\hline Juvenile Batten's disease & Seizures, visual loss, retinitis pigmentosa, dementia & $\begin{array}{l}\text { Skin or rectal biopsy for histological analysis, blood } \\
\text { for DNA analysis for the common mutation }\end{array}$ \\
\hline Leber's hereditary optic atrophy & $\begin{array}{l}\text { Bilateral optic atrophy (may be alcohol or tobacco } \\
\text { triggered) }\end{array}$ & Blood for mtDNA analysis \\
\hline $\begin{array}{l}\text { Neuropathy ataxia and retinitis pigmentosa } \\
\text { (NARP) }\end{array}$ & Retinitis pigmentosa, ataxia, neuropathy & Blood for mtDNA analysis \\
\hline Niemann-Pick disease type C & $\begin{array}{l}\text { Psychomotor retardation leading to dementia ataxia } \\
\text { with dystonia, vertical supranuclear ophthalmoplegia }\end{array}$ & $\begin{array}{l}\text { Bone marrow aspirate, fibroblast cholesterol uptake } \\
\text { and staining. }\end{array}$ \\
\hline Oculocutaneous albinism & Pale complexion, blue eyes & Hair follicle tyrosinase \\
\hline Refsum's disease & $\begin{array}{l}\text { Peripheral neuropathy, retinitis pigmentosa, } \\
\text { cerebellar ataxia }\end{array}$ & Plasma phytanic acid \\
\hline Sialidosis (mucolipidosis type I) & $\begin{array}{l}\text { Type I } \\
\text { Visual defect with lens or corneal opacityataxia, } \\
\text { myoclonus, generalised seizures sometimes with } \\
\text { nystagmus, ataxia, dementia } \pm \text { cherry red spot } \\
\text { Type II } \\
\text { Myoclonus, blindness, cherry red spot, dysmorphic } \\
\text { features, angiokeratoma. }\end{array}$ & $\begin{array}{l}\text { Urine oligosaccharides } \\
\text { Fibroblast } \alpha \text {-neuraminidase }\end{array}$ \\
\hline Tyrosinaemia type II & Cataracts, skin lesions, slight developmental delay & Plasma and urine amino acids \\
\hline Wilson's disease & $\begin{array}{l}\text { Cataracts, Kayser-Fleischer rings, liver disease, } \\
\text { dementia, renal failure, parkinsonian features, } \\
\text { dysarthria, loss of coordination of voluntary } \\
\text { movement. }\end{array}$ & Plasma copper and caeruloplasmin \\
\hline
\end{tabular}


Table 2 Symptom groups associated with adult onset inborn errors of metabolism (continued)

\begin{tabular}{|c|c|c|}
\hline Disorder & Other symptoms & Tests \\
\hline \multicolumn{3}{|c|}{ Epilepsy } \\
\hline Electron transport chain disorders & Any combination of symptoms & $\begin{array}{l}\text { CSF and blood lactate, blood mtDNA analysis, } \\
\text { muscle biopsy for enzyme assay. }\end{array}$ \\
\hline Juvenile Batten's disease & Visual loss & $\begin{array}{l}\text { Skin or rectal biopsy for histological analysis, DNA } \\
\text { for the common mutation }\end{array}$ \\
\hline Kuf's disease & Progressive myoclonic epilepsy & Skin or rectal biopsy for histological analysis \\
\hline Myoclonic epilepsy with ragged red fibres & Myoclonus & Blood for mtDNA analysis. \\
\hline Pyridoxine dependent seizures & Persistent seizures responsive to pyridoxine & Pyridoxine response trial (primary defect not known) \\
\hline Sialidosis (mucolipidosis type I) & $\begin{array}{l}\text { Type I } \\
\text { Visual defect with lens or corneal opacityataxia, } \\
\text { myoclonus, generalised seizures sometimes with } \\
\text { nystagmus, ataxia, dementia } \pm \text { cherry red spot } \\
\text { Type II } \\
\text { Myoclonus, blindness, cherry red spot, dysmorphic } \\
\text { features, angiokeratoma }\end{array}$ & $\begin{array}{l}\text { Urine oligosaccharides } \\
\text { Fibroblast } \alpha \text {-neuraminidase }\end{array}$ \\
\hline
\end{tabular}

homozygous for a common pseudodeficiency mutation in the arylsulphatase A gene. ${ }^{5}$

AMINO ACID AND ORGANIC ACID DISORDERS

Because environmental factors such as diet and stress (for example, infection and surgery) influence the metabolism of patients with amino acid and organic acid disorders they may not present with symptoms in childhood because they may not have been exposed to these factors. The stress of dieting, increased dietary intake, prolonged exercise (as in sport or training), or pregnancy may trigger the first recognised attack.

Defects in the urea cycle such as ornithine transcarbamylase deficiency, argininosuccinic aciduria, or citrullinaemia can cause hyperammonaemia often associated with a metabolic alkalosis. In adults this may present with intermittent episodes of coma or behavioural disturbance, which may be confused with a psychiatric disorder. ${ }^{7-9}$

The fatty acid oxidation defects generally present with hypoglycaemia, which can be so severe as to cause coma or, if not managed promptly, sudden death. Although adults are more resistant to fasting than children (a fast of over 24 hours is usually required to produce hypoglycaemia and fat mobilisation) they may become hypoglycaemic. ${ }^{10}$ Often detailed questioning about the clinical history will disclose what were probably mild hypoglycaemic attacks during childhood. The long chain fatty acid defects can also present with myoglobinuria and rhabdomyolysis after extreme exercise due to the inability of the skeletal muscle to utilise fatty acids for energy production. ${ }^{11}$

The carnitine transporter defect can result in very low cardiac muscle carnitine concentrations causing sudden death with a hypertrophic cardiomyopathy. ${ }^{12}$ As most of the fatty acid oxidation defects are treatable disorders, it is very important that they are promptly diagnosed.

Homocystinuria can occur in some disorders due to defects in different enzymes involved in the degradation of homocystine. The "classic" form of the disease is due to a deficiency of cystathionine synthase. This disorder may present in adulthood as late as 40 years of age with myopia, a history of thrombotic episodes, Marfanoid features, and mental retardation. ${ }^{13}$ The presence of ectopia lentis is a useful diagnostic sign. As some show a favourable response to vitamin $\mathrm{B} 6$ administration it is important to diagnose this disorder at an early stage.

PEROXISOMAL DISORDERS

For many years the role of the peroxisome in mammalian biochemistry remained unknown. The discovery, in the 1970s, that some neurogenetic syndromes were due to defects in metabolic pathways within this organelle led to the recognition of this group of disorders as significant causes of paediatric mortality and morbidity. ${ }^{14}$

Milder forms of disorders such as Zellweger's syndrome and rhizomelic chondrodysplasia punctata exist, but adult onset forms of these disorders have not yet been reported. The most commonly encountered adult onset disease within this group is X linked adrenoleukodystrophy (X linked adrenomyelopathy). ${ }^{15}$ The disorder is due to a defect in a peroxisomal membrane protein involved in the first step in the degradation of very long chain fatty acids (VLCFAs) - fatty acids with a chain length $>24$ carbons. These fatty acids are important components of brain lipids and their accumulation leads to demyelination which, in the childhood onset form, affects the brain, spinal cord, and peripheral nerves. In the adult onset form the brain is spared, the symptoms primarily reflecting demyelination of the spinal cord and peripheral nerves. The affected hemizygous males usually have a more severe presentation than the heterozygous females and the females may often present as "atypical multiple sclerosis". ${ }^{16}$

One important consequence of the accumulation of VLCFAs in the adrenal cortex is the development of adrenal dysfunction. This can present without overt neurological symptoms and if present in a relative of a patient with a demyelinating disease should raise the possibility of X linked adrenoleukodystrophy. ${ }^{15}$ All male patients with Addison's disease in whom there is no established cause should be tested 
for this disease by measurement of plasma VLCFAs.

\section{LACTIC ACIDAEMIAS}

Increased blood lactate occurs in a wide range of acquired and genetic conditions and lacks specificity. In CNS disease often a more specific indicator of inherited disturbances in lactate metabolism is the finding of increased CSF lactate. ${ }^{17}$ Increased CSF lactate $(>2.2$ $\mathrm{mmol} / \mathrm{l}$ ) in the presence of a normal or only marginally increased blood lactate is suggestive of defective lactate metabolism within the CNS.

A useful aid to differential diagnosis is the presence or absence of hypoglycaemia. Hypoglycaemia suggests a defect in glycogen metabolism, gluconeogenesis, or fatty acid oxidation. The absence of hypoglycaemia suggests a defect in the electron transport chain, Kreb's cycle, or pyruvate dehydrogenase ${ }^{18}$ although mtDNA depletion disorders may present with hypoglycaemia. ${ }^{19}$

Although to date no patients with adult onset symptoms with pyruvate dehydrogenase deficiency or a Kreb's cycle defect have been reported, many patients have been described with adult onset electron transport chain defects. Classically these present as myopathies with muscle weakness and ophthalmoplegia. However, it is now clear that patients can have a much wider range of clinical symptoms including endocrinological problems (diabetes mellitus, pseudohypoparathyroidism), ${ }^{20}$ cardiomyopathy (hypertrophic cardiomyopathy and the Wolf-Parkinson-White conduction defect), ${ }^{21}$ Fanconi syndrome, ${ }^{22}$ and liver disease. ${ }^{23}$ Any patient with multisystem disease, in whom the multiple abnormalities are not explicable as a "domino effect" or sequelae from primary organ dysfunction, should be investigated for an electron transport chain defect. This would require as a minimum the measurement of blood lactate and a blood sample for mitochondrial DNA analysis.

Some of the subunits of the electron transport chain are encoded by the mitochondrial DNA and some point mutations have been clearly associated with certain clinical groups with adult onset. These include Leber's hereditary optic atrophy (LHON), neuropathy ataxia and retinitis pigmentosa (NARP), mitochondrial encephalopathy with lactic acidaemia and stroke-like episodes (MELAS), and myoclonic epilepsy with ragged red fibres (MERRF). ${ }^{23}$ Also a large proportion of patients with Kearns-Sayre syndrome and chronic progressive ophthalmoplegia (CPEO) have deletions in the mitochondrial DNA. ${ }^{24}$ However, to diagnose these disorders a muscle biopsy is usually required, as the mutated DNA may not be present in an unaffected tissue such as blood or fibroblasts. ${ }^{25}$ To detect defects in nuclear encoded electron transport chain subunits a muscle biopsy for enzyme assay is usually required.
DISORDERS OF THE GLYCOGENOLYTIC AND GLYCOLYTIC PATHWAYS

Glycogen catabolism to pyruvate generates ATP, which is used for biosynthetic reactions and for muscle contraction. It is an anaerobic pathway that predominates in type IIb muscle fibres but is also a major pathway in type IIa fibres. A defect in this pathway results in impaired ATP production in muscle manifesting as exercise intolerance and in excess glycogen storage. If the liver pathway is also affected hypoglycaemia or liver disease may also result.

The most commonly recognised adult onset disorder within this group is glycogen storage disease type V (McArdle's disease) which is due to a deficiency of a muscle specific glycogen phosphorylase. ${ }^{26}$ It is often associated with a "second wind" phenomenon wherein the pain associated with moderate exercise progressively disappears even if exercise is prolonged. The mechanism for this is not as yet clearly defined; however, it is thought to be related to increased blood flow after ischaemic exercise and to fat mobilisation to provide fatty acids for energy production in muscle. Defects in the enzymes responsible for the activator system for glycogen phosphorylase (for example, phosphorylase b kinase) may also present with muscle weakness although liver disease or cardiomyopathy may also have been noted at some time. ${ }^{27}$

There is an atypical presentation of a glycogen brancher enzyme deficiency called adult polyglucosan body disease. Although in children this disorder presents with liver or muscle disease it presents in these adults with purely neurological symptoms ${ }^{28}$ with progressive upper and lower motor neuron disease, sensory loss, neurogenic bladder, and dementia. The CNS has a functional pathway for glycogen catabolism (although glucose cannot be released extracellularly) and these abnormalities may reflect the importance of this pathway in normal CNS function.

There is a range of disorders due to deficiencies in the enzymes of the glycolytic pathway. They present with muscle weakness and exercise intolerance. In some cases, as the gene involved also codes for an erythrocyte enzyme, they may present with haemolytic anaemia. ${ }^{26}$

Phosphofructokinase deficiency (Tauri's disease) overlaps both groups in that whereas the enzyme is part of the glycolytic pathway there is moderate glycogen storage. However, there are no hepatological symptoms and hypoglycaemia is not a feature.

These disorders are usually diagnosed on muscle biopsy by enzyme analysis in a specialist centre. There is a common mutation for McArdle's disease, which may obviate the need for a biopsy if it is detected by DNA analysis of blood. ${ }^{29}$ Disorders of the glycolytic pathway which affect erythrocyte as well as muscle function may also be detectable by assays in red cells.

OTHER DISORDERS

Disorders such as Wilson's disease ${ }^{30}$ and porphyrias $^{31}$ are well established as adult inborn errors of metabolism. However, it is not 
always appreciated that Lesch-Nyhan syndrome (hypoxanthine: guanine phosphoribosyl transferase deficiency) may sometimes present with neurological symptoms in adulthood. In these patients the main presenting feature is athetosis without cognitive impairment or behavioural abnormalities. ${ }^{32}$ Renal stones may occur due to the insolubility of uric acid.

Cerebrotendinous xanthomatosis is a disorder of bile acid metabolism due to a deficiency of mitochondrial sterol 27-hydroxylase. In the later onset forms the key diagnostic clue is tendon xanthomas. ${ }^{33}$

\section{Diagnosing inborn errors of metabolism in adults}

When presented with a patient it is most important to "think metabolic." A history of intermittent attacks triggered by feeding or fasting or some stress factor may suggest a disorder of the urea cycle, amino acid catabolism, or fatty acid oxidation. A slow progressive course may suggest a lysosomal storage disease or a peroxisomal disorder. Often detailed questioning may disclose evidence of problems in childhood or adolescence. A family history may at first not seem revealing; however, the occurrence in members of apparently different symptoms may indicate an inborn error of metabolism the expression of which is modified by environmental or other genetic factors.

Many adults with inborn errors of metabolism have shown mild clinical symptoms at an early age. These often remain unrecognised, particularly if they are relatively "soft" or are intermittent in nature. Even patients with an early onset of progressive diseases may, with appropriate care, plateau out and survive well into adulthood.

Specific neurological signs such as vertical supranuclear ophthalmoplegia or a cherry red spot may suggest a particular metabolic disease. Alternatively there may be abnormalities affecting other organ systems, such as hypertrophic cardiomyopathy, liver disease, or dysmorphic features.

The baseline investigations performed will depend on the clinical features and most can be done in local district general hospital clinical chemistry laboratories. More specialised tests should be sent to the Regional Metabolic Disease Service. The local clinical chemistry laboratory should know the address of the nearest centre and will help with information and specimens requiring shipment. Most specialist centres usually perform analyses for amino acids, organic acids, very long chain fatty acids, some lysosomal enzyme assays, and there is a network of laboratories involved in inborn errors of metabolism that can supply details of addresses for those performing more specialised tests. ${ }^{34}$

1 Garrod AG. Inborn errors of metabolism. Oxford: Oxford University Press, 1909.
2 Federico A, Ciacci G, D'Amore I, et al. GM2 gangliosidosis with hexosaminidase A and B defect: report of family with motor-neurone disease like phenotype. F Inherit Metab Dis 1986;9:307-10.

3 Hardie RJ, Young EP, Morgan-Hughes JA. Hexosaminidase A deficiency presenting as juvenile progressive dystonia. $\mathcal{F}$ Neurol Neurosurg Psychiatry 1988;51:446-59.

4 Thomas PK, Young E, King RHM. Sandhoff's disease mimicking adult-onset bulbospinal neuronopathy. $\mathcal{F}$ Neurol Neurosurg Psychiatry 1989;52:1103-6.

5 Baumann N, Masson M, Casseau V, et al. Adult forms of metachromatic leucodystrophy: clinical and biochemical approach. Dev Neurosci 1991;13:211-15.

6 Felice KJ, Alessi AG, Grumnet ML. Clinical variability in adult-onset acid maltase deficiency: report of affected sibs and review of the literature. Medicine 1995;74:131-5.

7 Dimagno EP, Lowe JE, Snodgrass P, et al. Ornithine Dimagno EP, Lowe JE, Snodgrass $\mathrm{P}$, et al. Ornithine
transcarbamylase deficiency-a cause of bizarre behaviour transcarbamylase deficiency-a cause
in a man. $N$ Engl $\mathcal{F}$ Med 1986;315:744.

8 Finkelstein JE, Hauswer ER, Leonard CO, et al. Late onset ornithine transcarbamylase deficiency in male patients. fAMA 1988;260:3167.

9 Arn PH, Hauser ER, Thomas GH, et al. Hyperammonaemia in women with a mutation at the ornithine transcarbamylase locus. A cause of post partum coma. $N$ Engl $\mathcal{F}$ Med 1990;322:1652-5.

10 Gray RGF, Preece MA, Seddon H, et al. Two adults with medium chain acyl CoA dehydrogenase deficiency. $A b-$ stracts of the Annual Symposium of the Society for the Study of Inborn Errors of Metabolism. Lancaster: Kleuver Academic Publishers, 1995:114.

11 Di Mauro S, Papadimitrou A. Carnitine palmitoy ltransferase deficiency. In: Engel AG, Barker GQ, eds. Myology: basic and clinical. New York: McGraw Hill, 1986.

12 Teim I, De Vivo DC, Ranucal D, et al. Skin fibroblast carnitine uptake in secondary carnitine deficiency disorders. $\mathcal{F}$ tine uptake in secondary carnitine
Inherit Metab Dis 1993;16:135-46.

13 Cruysberg JRM, Boers GHJ, Trijbels JMC, et al. Delay in diagnosis of homocystinuria: retrospective study of consecutive patients. BMF 1996;313:1037-40.

14 Wanders RJA, Heymans HSA, Schutgens RBH, et al. Peroxisomal disorders in neurology. F Neurol Sci 1988;88: $1-39$.

15 Moser HW, Adrenoleucodystrophy: phenotype, genetics, pathogenesis and therapy. Brain 1997;120:1485-508.

16 Dooley JM, Wright BA. Adrenoleucodystrophy mimicking multiple sclerosis. Can $\mathcal{F}$ Neurol Sci 1985;12:73.

17 Hutchesson A, Preece MA, Gray G, et al. Measurement of lactate in cerebrospinal fluid in the investigation of inherited metabolic disease. Clin Chem 1997;43:158-61.

18 Brown GK, Otero LJ, Le Gris M, et al. Pyruvate dehydrogenase deficiency. F Med Genet 1994;31:875-9.

19 Morris AA, Taanman JW, Blake J, et al. Liver failure associated with mitochondrial DNA depletion. If Hepatol ated with mitoch

20 Tulinius $\mathrm{MH}$, Oldfors A, Holme E, et al. Atypical presentation of multisystem disorders in two girls with mtDNA deletions. Eur F Pediatr 1995;154:35-42.

21 Guenthard J, Wyler F, Fowler B, et al. Cardiomyopathy in respiratory chain disorders. Arch Dis Child 1995;72:223-6.

22 Grunfeld J-P, Niaudet P, Rotig A. Renal involvement in mitochondrial cytopathies. Nephrol Dial Transplant 1996; 11:760-1.

23 Sokol RJ. Expanding spectrum of mitochondrial disorders. $\mathcal{f}$ Pediatr 1996;128:597-9.

24 Harding AE, Hammans SR. Deletions of the mitochondrial genome. F Inherit Metab Dis 1992;15:480-6.

25 Munnich A, Rotig A, Chretien D, et al. Clinical presentations and laboratory investigations in respiratory chain deficiency. Eur F Pediatr 1996;155:262-74.

26 Moses SW. Muscle glycogenosis. F Inherit Metab Dis 1990;13:452.

27 Clemens PR, Yamamoto MR, Engel AG. Adult phosphorylase b kinase deficiency. Ann Neurol 1990;28:529.

28 Bruno C, Servidei S, Shanske S, et al. Glycogen branching enzyme deficiency in adult polyglucosan body disease. Ann Neurol 1993:33:88-93.

29 Bartram C, Edwards RHT, Clague J, et al. McArdle's disease: a nonsense mutation in exon 1 of the muscle glycogen phosphorylase gene explains some but not all cases. Hum Molec Genet 1993;8:1291-3.

30 Gollan JL, Gollan TJ. Wilson's disease in 1998: genetic, diagnostic and therapeutic aspects. f Hepatol 1998; 28(suppl 1):28-36.

31 Elder GH, Hift RJ, Meissner PN. The acute porphyrias. Lancet 1997;349:1613-17.

32 Puig JG, Torres RJ, Mateos FA, et al. The spectrum of HGPRT deficiency. Clinical experience based on 20 patients from 16 Spanish families. Adv Exp Med Biol 1998; 421:25-9.

33 Datli MT, Salen G, Federico A. Cerebrotendinous xanthomatosis as a multisystem disease mimicking premature ageing. Dev Neurosci 1991;13:371-6.

34 Pennock C, Stone J, eds. UK Directory of Laboratories Diagnosing Inborn Errors of Metabolism, 6th edition. Bristol: BIMDG, 1998. 